\title{
Deep into the ice: over-wintering and habitat selection in male Atlantic walruses
}

\author{
Carla Freitas $^{1,2, *}$, Kit M. Kovacs ${ }^{1}$, Rolf A. Ims ${ }^{2}$, Michael A. Fedak ${ }^{3}$, Christian Lydersen ${ }^{1}$ \\ ${ }^{1}$ Norwegian Polar Institute, Polar Environmental Centre, 9296 Tromsø, Norway \\ ${ }^{2}$ Institute of Biology, University of Tromsø, 9037 Tromsø, Norway \\ ${ }^{3}$ NERC Sea Mammal Research Unit, Gatty Marine Laboratory, School of Biology, University of St. Andrews, St. Andrews, \\ Fife KY16 8LB, UK
}

\begin{abstract}
New technological developments in animal-borne satellite-tracking devices in combination with increased access to satellite-based environmental data are creating new possibilities for studying movement patterns and habitat selection by animals in remote, logistically challenging environments. In the present study, we report the first year-round data on movement patterns of walruses in the High Arctic, including at-sea positions. Using first-passage times (FPT) to study habitat use and quantifying habitat selection using mixed-effects Cox proportional hazards models, we dispelled the conventional perception that seasonal movement patterns of Atlantic walruses are simply a result of them following the retraction and expansion of annually formed sea ice. Walruses in this study ( $\mathrm{n}=17$ males) actively moved into areas of high ice concentration (>90\%) during winter; travelling far into the ice pack, as far as $600 \mathrm{~km}$ from ice-free water. Additionally, high inter-annual, seasonal site fidelity was documented. Seasonal differences in habitat use patterns were also observed. In summer, when walruses feed intensively, FPTs were affected by water depth and distance to the coast $\left(\mathrm{R}^{2}=0.571\right)$, but these variables had no effect on walrus habitat use in winter. Sea ice concentration was the most important environmental condition during the winter season $\left(\mathrm{R}^{2}=0.162\right)$, though there are clearly other factors influencing where individuals occur in winter that are currently unaccounted for in these analyses. The male walruses in this study did not do much benthic diving during winter, suggesting that they did not feed often during the time that they are known to breed. Instead, they remained in areas with high ice coverage, far from their coastal summering areas, spending much of their time hauled out or in surface waters.
\end{abstract}

KEY WORDS: Cox proportional hazards models $\cdot$ First-passage time $\cdot$ Odobenus rosmarus rosmarus Random-effects models $\cdot$ Satellite telemetry $\cdot$ Site fidelity

Resale or republication not permitted without written consent of the publisher

\section{INTRODUCTION}

The study of movement patterns and habitat selection has been a fundamental component of animal ecology for many decades (e.g. Manly et al. 2002, Fortin \& Dale 2005). But, in marine mammal research, this field has progressed slowly compared to terrestrial studies because of the technological problems encountered in attempting to track animals at sea (Cooke et al. 2004). New tag technology (e.g. Fedak et al. 2002,
McConnell et al. 2004, Robinson et al. 2006), in combination with greater access to satellite-based and other environmental data, as well as new statistical approaches to the study of animal movements in relation to environmental correlates (e.g. Aarts et al. 2008, Freitas et al. 2008b), are opening up new possibilities for studying animals even in remote, very logistically challenging environments. Extensive sea ice, harsh weather and sea conditions, in addition to $24 \mathrm{~h}$ winter darkness has limited our ability to work with large, 
highly mobile Arctic marine mammals, leaving winter ecology and habitat use largely enigmatic for many species. The new possibilities to study these 'problematic' animals and the environmental conditions they experience by using remote methods are very timely, because the Arctic is currently undergoing dramatic environmental change (ACIA 2005, Solomon et al. 2007). Monitoring a resident population's responses will provide considerable insight into their adaptability and permit assessments of their survival potential.

Walruses Odobenus rosmarus are full-time residents of the Arctic. Our current knowledge of their movement patterns and habitat selection choices is a composite built from bits of information from many, different sources, including aboriginal hunting knowledge and catch records (e.g. Lønø 1972, Fay 1982, Fay et al. 1984), natural history observations, some of which date back to early Arctic explorers (e.g. Allen 1880 and references therein, Manning 1944, Mansfield 1958, 1966), military flights and naval operations (e.g. Fay 1982), inferences from isotope patterns in teeth (Stewart et al. 2003), as well as some dedicated studies of behaviour and demographics (e.g. Miller 1982, Miller \& Boness 1983, Born \& Knutsen 1992, 1997, Knutsen 1993, Gjertz \& Wiig 1995, Sjare \& Stirling 1996, Wiig et al. 1996, Gjertz et al. 2001, Jay \& Hills 2005, Lydersen et al. 2008). Not surprisingly, most of the available behavioural information about walruses is restricted to the seasons in which there is daylight in the High Arctic (i.e. not in the winter). Some data are available from both walrus subspecies (Atlantic: O. r. rosmarus; Pacific: O. r. divergens), but our general picture of walrus ecology is often dominated by Fay's (1982) monograph on the Pacific walrus.

During summer, male walruses occur mainly in seasonally ice-free coastal, shallow water $(80$ to $100 \mathrm{~m}$ deep) areas, where they feed on bottom-dwelling bivalve molluscs, hauling-out on land intermittently to rest (Fay 1982, Gjertz \& Wiig 1992, Wiig et al. 1993, Fisher \& Stewart 1997, Gjertz et al. 2001, Born et al. 2003). Females and calves seem to prefer to remain in association with drifting ice as much as is possible, but they too occur in coastal areas in summer throughout the range of the species (Fay 1982, Miller 1982, Miller \& Boness 1983, Gjertz \& Wiig 1994). The reproductive status of hunted specimens and the single observational study of mating behaviour conducted to date indicate that mating takes place from January to April (Mansfield 1966, Fay 1982, Fay et al. 1984, Sjare \& Stirling 1996, Born 2001, 2003). Breeding locations for most walrus populations are unknown. However, during the winter and early spring, male and female walruses in the Pacific are found mainly in pack-ice areas close to ice edges (Fay 1982, Fay et al. 1984). It is believed that Pacific walruses follow the seasonal advance and retreat of sea ice throughout the year, migrating south in winter and north in summer (Fay 1982, 1985). The same pattern has been assumed to occur for Atlantic walruses, though little movement information is in fact available. Locally, in the eastern Canadian Arctic and West Greenland, distribution is thought to be governed by bathymetry, ice conditions and the influence of native settlements (Born et al. 1995).

Studying movement patterns and habitat selection directly via the deployment of satellite-linked tags on walruses has proven to be very challenging. These large animals are not easily anesthetised, and they are very rough on instruments. Previous telemetry studies have been attempted in both Atlantic (Born \& Knutsen 1992, 1997, Wiig et al. 1996, Born et al. 2005, Born \& Acquarone 2007) and Pacific walruses (Jay \& Hills 2005). However, the durations of data records have not been long enough to reveal breeding locations in most cases, at-sea position data have not been received by the satellite platform and relatively little habitat analysis has been conducted.

Atlantic walruses in Svalbard (Norway) and Franz Josef Land (FJL; Russia) belong to a single population (Born et al. 1995, Andersen et al. 1998). In these High Arctic archipelagos, 4 centuries of harvesting severely depleted the walrus population, especially in Svalbard (Lønø 1972, Born 1984, Born et al. 1995, Gjertz \& Wiig 1995). Recovery has been taking place since walruses became protected during the early 1950s (Born 1984, Gjertz \& Wiig 1995). Currently, the summering population in Svalbard is estimated to be approximately 2600 individuals (Lydersen et al. 2008). Walruses found along the coasts of Svalbard are predominantly males (Gjertz \& Wiig 1994); females are rarely observed beyond a small area in the far NE corner of the archipelago (Gjertz \& Wiig 1994). Females and calves are, however, common in FJL (Knutsen 1993, Gjertz \& Wiig 1994). Although walruses in Svalbard and FJL form a single population, and movements between the 2 archipelagos have been reported during summer and autumn (Wiig et al. 1996), it is not known if male walruses from Svalbard travel to FJL in winter/spring to mate. It is possible that females from FJL migrate south in winter, as they are purported to do in the Pacific, and that mating areas occur south of that archipelago.

In the present study, annual movements and habitat selection by male walruses tagged in Svalbard in the summers of 2003 and 2004 were investigated, with special emphasis on their movement patterns and habitat-use during winter. Based on male movements during that time of the year, breeding locations and the duration of breeding were also investigated. Fidelity to feeding and breeding areas between years was also explored. 


\section{MATERIALS AND METHODS}

Field methods and data handling. A total of 17 male walruses were equipped with custom-designed, satellite-relayed data loggers (SRDL) in August 2003 ( $\mathrm{n}=9$ ) and August 2004 ( $\mathrm{n}=8$ ) in Svalbard, Norway (Table 1, Fig. 1). The SRDLs were designed to give information on the movements (geographic position), haulout time and diving behaviour (depth) of the walruses (see Lydersen et al. 2008 for design details, SRDLs produced by SMRU, St. Andrews University). Animal handling procedures followed Griffiths et al. (1993), with the methodological modifications described by Lydersen et al. (2008). All animal-handling protocols used in this study were approved by the Governor of Svalbard (Sysselmannen) and the Norwegian Animal Research Authority. A SRDL was attached to the left tusk of the immobilised individual using stainless steel hose clamps. Tusk length and circumference at the base were measured $( \pm 1 \mathrm{~cm})$; tusk volume (or mass) increases continually with age in walruses and, hence, provides a crude estimator of age (Fay 1982). Volume $(V)$ was calculated assuming that tusks were cone-shaped, using the relationship:

$$
V=\frac{1}{3} \pi r^{2} h
$$

where $r$ is tusk radius and $h$ is the length of the tusk.

The SRDLs provided position, dive and haulout data. These data were received through the Advanced
Research and Global Observation Satellite (ARGOS) system of geosynchronous satellites. The SRDLs were programmed to send these data whenever possible, with a transmission rate of up to 250 transmissions $\mathrm{d}^{-1}$ during the first $100 \mathrm{~d}$ and 140 transmissions $\mathrm{d}^{-1}$ thereafter. ARGOS locations are estimated by Doppler shift (not by GPS). Because of the high number of low-accuracy locations, ARGOS locations were filtered using the algorithm described by Freitas et al. (2008c) and available within the $\mathrm{R}$ software package 'argosfilter' (http://cran.r-project.org/; function sdafilter with all default settings). Filtering aimed to remove locations requiring unrealistic swimming speeds $\left(>2 \mathrm{~m} \mathrm{~s}^{-1}\right)$ and unlikely turning angles (>165 degrees or >155 degrees, depending on the length of path deviations). Quality ' $Z$ ' locations (for which the location assessment process failed; see ARGOS 1996) were also removed.

Movement parameters and home range analysis. Distances travelled and travelling speeds were calculated using ArcInfo (ESRI, Inc.). In order to investigate home range size and site fidelity throughout the year, home ranges were calculated for each month for each walrus, using the $100 \%$ minimum convex polygon (MCP) method (Mohr 1947). This simple method was chosen since it provides the limits of the overall area used by each individual, which was the focus of interest in the present analysis. First and last months in the data sets were excluded from this analysis if they did not contain a minimum of $20 \mathrm{~d}$ of data. Calculations were made using the package 'adehabitat' in $\mathrm{R}$. The

Table 1. Odobenus rosmarus. Summary of tracking records and tusk measurements of 17 adult male walruses equipped with satellite-relayed data loggers in Svalbard in 2003 and 2004. Seasons tracked — S: summer; W: winter. Wintering area-SS: south Svalbard; WS: west Svalbard; NES: northeast Svalbard; K: Kvitøya; FJL: Franz Josef Land; * same as the tagging area; ${ }^{* *}$ travelled to FJL in summer, did not concentrate time in any particular area during winter

\begin{tabular}{|c|c|c|c|c|c|c|c|c|c|c|}
\hline $\begin{array}{l}\text { Walrus } \\
\text { ID }\end{array}$ & $\begin{array}{c}\text { First } \\
\text { location }\end{array}$ & $\begin{array}{c}\text { Last } \\
\text { location }\end{array}$ & $\begin{array}{c}\text { No. } \\
\text { days } \\
\text { tracked }\end{array}$ & $\begin{array}{c}\text { No. } \\
\text { raw } \\
\text { locations }\end{array}$ & $\begin{array}{c}\text { No. } \\
\text { filtered } \\
\text { locations }\end{array}$ & $\begin{array}{l}\text { Seasons } \\
\text { tracked }\end{array}$ & $\begin{array}{c}\text { Wintering } \\
\text { area }\end{array}$ & $\begin{array}{l}\text { Tusk } \\
\text { length } \\
(\mathrm{cm})\end{array}$ & $\begin{array}{l}\text { Tusk } \\
\text { perimeter } \\
(\mathrm{cm})\end{array}$ & $\begin{array}{c}\text { Tusk } \\
\text { volume } \\
\left(\mathrm{cm}^{3}\right)\end{array}$ \\
\hline 2003_01 & 6 Aug 2003 & 30 Mar 2004 & 237 & 1110 & 765 & $\mathrm{~S} / \mathrm{W}$ & $\mathrm{SS}^{*}$ & 42 & 19 & 402 \\
\hline 2003_02 & 6 Aug 2003 & 5 May 2004 & 273 & 1197 & 760 & $\mathrm{~S} / \mathrm{W}$ & $\mathrm{SS}^{*}$ & 34 & 19 & 326 \\
\hline 2003_03 & 6 Aug 2003 & 22 Oct 2004 & 443 & 2240 & 1483 & $\mathrm{~S} / \mathrm{W} / \mathrm{S}$ & FJL & 53 & 24 & 810 \\
\hline 2003_04 & 6 Aug 2003 & 24 Mar 2004 & 231 & 1182 & 846 & $\mathrm{~S} / \mathrm{W}$ & $-{ }^{* *}$ & 37 & 20 & 393 \\
\hline 2003_05 & 6 Aug 2003 & 14 Feb 2004 & 192 & 1112 & 512 & $\mathrm{~S} / \mathrm{W}$ & $\mathrm{K}$ & 43 & 22 & 552 \\
\hline 2003_06 & 6 Aug 2003 & 23 Mar 2004 & 230 & 1395 & 875 & S/W & FJL & 39 & 23 & 547 \\
\hline 2003_07 & 6 Aug 2003 & 30 Oct 2004 & 451 & 1667 & 1046 & S/W/S & NES & 45 & 17 & 345 \\
\hline 2003_08 & 5 Aug 2003 & 4 Mar 2004 & 212 & 1319 & 809 & $\mathrm{~S} / \mathrm{W}$ & WS & 45 & 19 & 431 \\
\hline 2003_09 & 6 Aug 2003 & 5 Nov 2004 & 457 & 2133 & 1481 & $\mathrm{~S} / \mathrm{W} / \mathrm{S}$ & $\mathrm{K}$ & 46 & 17 & 353 \\
\hline 2004_01 & 5 Aug 2004 & 29 Jan 2005 & 177 & 378 & 239 & $\mathrm{~S} / \mathrm{W}$ & NES & - & 24 & - \\
\hline 2004_02 & 5 Aug 2004 & 16 Dec 2004 & 133 & 563 & 294 & $\mathrm{~S} / \mathrm{W}$ & NES & 43 & 19 & 412 \\
\hline 2004_03 & 4 Aug 2004 & 7 Oct 2004 & 64 & 497 & 353 & $\mathrm{~S}$ & - & - & - & - \\
\hline 2004_04 & 5 Aug 2004 & 12 Mar 2005 & 219 & 793 & 585 & $\mathrm{~S} / \mathrm{W}$ & $\mathrm{K}$ & 40 & 22 & 514 \\
\hline 2004_05 & 5 Aug 2004 & 31 Mar 2005 & 238 & 1962 & 1229 & S/W & $\mathrm{K}$ & 37 & 21 & 433 \\
\hline 2004_06 & 4 Aug 2004 & 17 Sep 2005 & 409 & 1007 & 720 & S/W/S & NES & 48 & 30 & 1146 \\
\hline 2004_07 & 4 Aug 2004 & 25 Feb 2005 & 205 & 221 & 163 & S/W & NES & 50 & 19 & 479 \\
\hline 2004_08 & 5 Aug 2004 & 6 Feb 2006 & 550 & 1529 & 1035 & $\mathrm{~S} / \mathrm{W} / \mathrm{S} / \mathrm{W}$ & K & 43 & 20 & 456 \\
\hline Mean & & & 278 & & & & & & & \\
\hline $\mathrm{SE}$ & & & 32.4 & & & & & & & \\
\hline
\end{tabular}



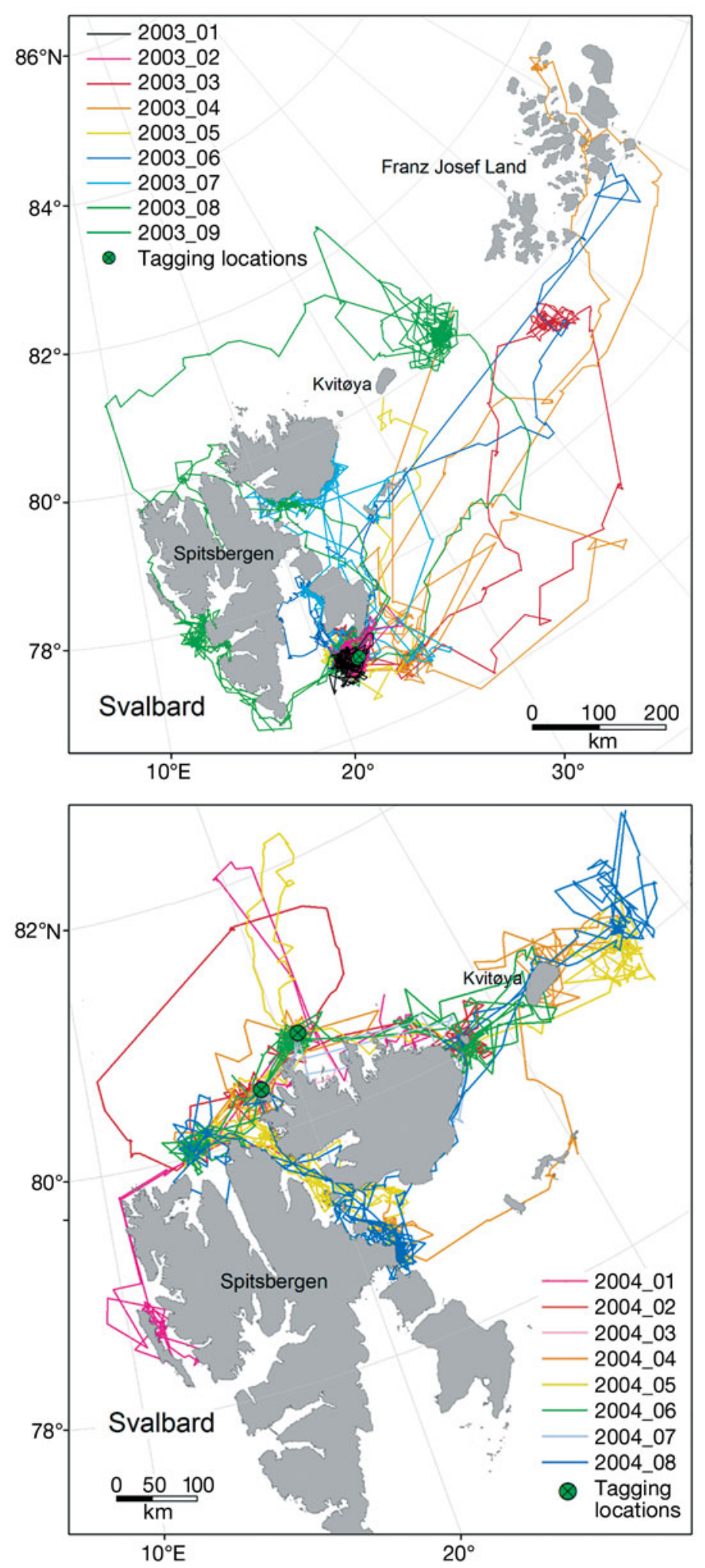

Fig. 1. Odobenus rosmarus. Tracks of 17 male walruses equipped with satellite-relayed data loggers in Svalbard in 2003 (upper panel) and 2004 (lower panel), filtered following the method described by Freitas et al. (2008c) percentage overlap between home ranges was calculated, using the R package 'spatstat'.

Habitat selection analysis. Using the filtered locations and assuming that walruses travelled linearly at constant speed between those locations, a set of positions was generated every $10 \mathrm{~km}$ along the track of each individual. This resolution $(10 \mathrm{~km})$ was chosen in order to have a resolution equal to, or lower than, the resolution of the environmental variables used to explore habitat selection (see below). Filtered locations were spaced at median $( \pm \mathrm{SE})$ distances of $3.0 \pm 0.1 \mathrm{~km}$, and thus had a finer resolution than the generated positions. First-passage times (FPT) were then calculated for each of the generated positions, in order to obtain a measure of habitat use intensity along the track. FPT is defined as the time required for a tracked animal to cross a circle of a given radius (see Fauchald \& Tveraa 2003). FPTs were calculated for every position for radii ranging from 10 to $100 \mathrm{~km}$ (by $10 \mathrm{~km}$ increments). The variances of the log-transformed FPTs were then plotted for each individual in order to identify the radius of maximum variance. This radius corresponds to the spatial scale at which the animal concentrated its time and, hence, is the scale that best differentiates between high and low passage times (Fauchald \& Tveraa 2003, 2006). The scale of maximum variance (mean scale for all study individuals) was found to be $40 \mathrm{~km}$ (Fig. 2). FPTs at this scale were used to compare the time spent by walruses in different parts of their tracks. Note that a common scale was used to make interindividual comparisons possible.

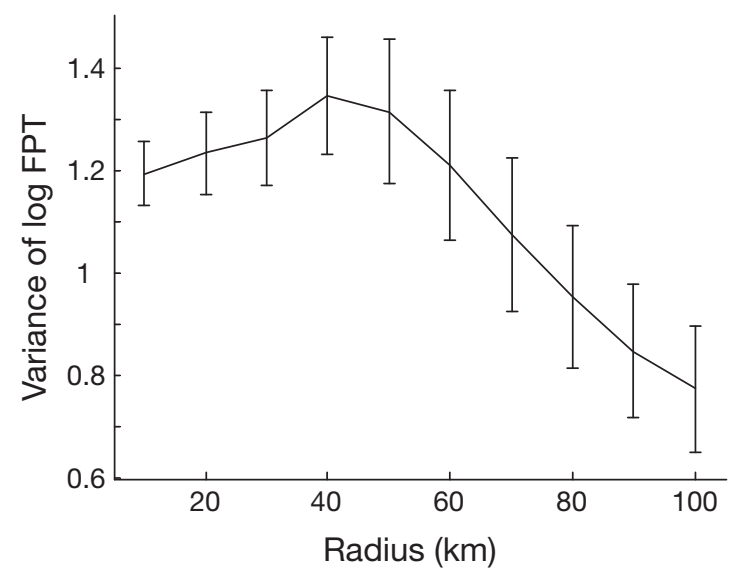

Fig. 2. Odobenus rosmarus. Mean variance $( \pm \mathrm{SE})$ in log-transformed first-passage times (FPT) as a function of radius for the 17 male walruses tagged in Svalbard in 2003 and 2004. The peak in variance occurred at a radius of $40 \mathrm{~km}$ 
In order to explore the hypothesis that habitat selection during the breeding (winter) and feeding (summer) seasons were driven by different environmental conditions, FPTs were analysed separately for these 2 seasons. Atlantic walruses breed during winter and spring, mainly between January and April (Mansfield 1966, Sjare \& Stirling 1996, Born 2001, 2003); males feed little during that season, but feed intensively during summer (Fay 1982). In order to identify possible breeding areas (where walruses had high FPTs), walrus locations in each track were colour-coded to aid visualization, according to the FPTs at a $40 \mathrm{~km}$ radius. Areas where walruses concentrated their time during winter/early spring were categorised as breeding areas (see Fig. 3). All other locations, except movements to/from breeding areas were categorised as feeding areas. To further explore the use of wintering and summering areas, diving behaviour of these ben-

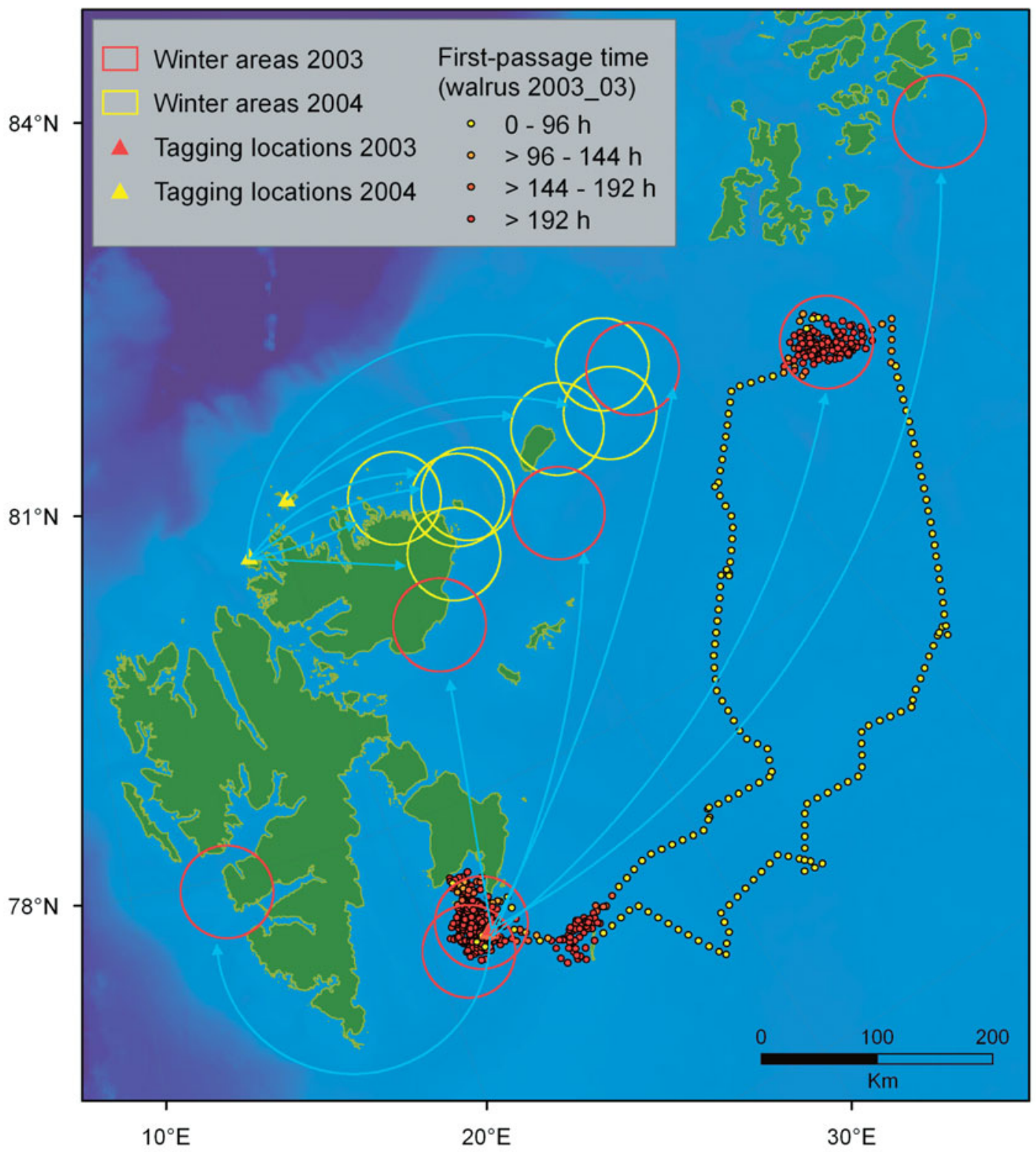

Fig. 3. Odobenus rosmarus. Areas where walruses tracked in this study concentrated their time during the winter/breeding season (circles). Note that one walrus was not tracked during winter (walrus 2004_03), and another did not concentrate its time in any particular area during winter (2003_04); therefore only 15 wintering/breeding areas are shown. Walruses were tagged in Svalbard in 2003 and 2004, in the locations indicated by the triangles. The detailed track information for 1 walrus (2003_03) (10 km spaced positions) is presented as an example of an actual track. It is colour-coded according to first-passage time (FPT, $40 \mathrm{~km}$ radius); colours range from yellow (low FPTs) to red (high FPTs) 
thic feeders was investigated in a preliminary fashion, comparing maximum depth of each dive with bathymetry in areas of high usage on a seasonal basis (detailed analyses of diving behaviour will be published separately). Sea bottom depths were extracted from $2.5 \mathrm{~km}$ resolution grid data from IBCAO (International Bathymetric Chart of the Arctic Ocean, Version 1.0, 2001). Note that all dives performed by the tracked animals are recorded by the SRDLs, but not all of them are received through the ARGOS system (because of satellite availability or transmission interruptions when the antenna is submerged). In this study dive information was available for $76.0 \pm 4.4 \%$ of the tracking time (mean $\pm \mathrm{SE}, \mathrm{n}=17$ walruses), with a total of 109741 dives being received during the entire tracking time).

In order to investigate habitat conditions associated with walrus habitat utilization (walrus FPTs) in breeding and non-breeding areas, a set of environmental conditions that could potentially affect FPTs were obtained for the same positions where FPTs were calculated. The variables included were: sea ice concentration (percent of water covered by sea ice), water depth, distance to the coast and distance to the nearest glacier front. The latter variable was included because coastal glacier fronts are known to attract other Arctic marine mammals because of the high levels of productivity generated in these areas (e.g. Lydersen et al. 2001, Freitas et al. 2008a). It is highly likely that seabottom sediment type also affects habitat use by these benthic feeders, but such data are not available for the study area. Sea ice concentrations were obtained from daily $10 \mathrm{~km}$ resolution data from OSI-SAF (The Ocean and Sea Ice Satellite Application Facility), which are derived from NASA SSM/I data. Depths were extracted from $2.5 \mathrm{~km}$ resolution grid data from IBCAO. Distances to the coast and to the nearest glacier front were calculated from Norwegian Polar Institute digital maps (updated using aerial photographs of glacier fronts and coastlines taken from 1993 to 1998).

The effect of habitat attributes on FPTs was first investigated by plotting the bootstrapped $95 \%$ confidence intervals (CIs) of FPTs as a function of the variable of interest. CIs were obtained using the percentile method (with 5000 bootstrapping samples). The effect of all habitat conditions on FPTs was then investigated by modelling FPTs, as a function of these variables, using Cox proportional hazard models ( $\mathrm{CPH}$ models; Cox 1972). A detailed description of this method was presented by Freitas et al. (2008b) The CPH model is written as:

$$
h(t)=\exp \left(\beta_{1} X_{1}+\beta_{2} X_{2}+\beta_{3} X_{3}+\ldots+\beta_{p} X_{p}\right) h_{0}(t)
$$

where $h(t)$ is the hazard function, i.e. the risk of an animal leaving an area at time $t . X_{1}, X_{2}, X_{3}, \ldots, X_{p}$ are the explanatory variables in the model, and $\beta_{1}, \beta_{2}, \beta_{3}, \ldots, \beta_{p}$ are the coefficients that describe the contribution of these variables. $h_{0}(t)$ is the baseline hazard function at time $t$, i.e. the risk of leaving an area where all explanatory variables are equal to zero or to a defined base value. In order to take individual variability into account, a random-effect term $(b)$ was added to the general CPH model, as described by Pankratz et al. (2005):

$$
h(t)=\exp \left(\beta_{1} X_{1}+\beta_{2} X_{2}+\beta_{3} X_{3}+\ldots+\beta_{p} X_{p}+b\right) h_{0}(t)
$$

where $b$ is the per-subject random effect. This modification of the general CPH model allows for analysis of time-based event data that have a nested variance structure.

Selection of the best model was based on the Akaike's information criterion, corrected to the effective sample size $\left(\mathrm{AIC}_{\mathrm{c} i}\right.$ Burnham \& Anderson 2002). All possible combinations of variables were considered during model selection. The key assumption of proportional hazards required by the $\mathrm{CPH}$ model was tested by checking the scaled Schoenfeld residuals, both visually and by testing if their slope was zero (see Collett 2003). The variable 'distance to glacier' was evaluated by the bootstrap procedure explained above, which showed that it had no clear effect on habitat selection. In addition this variable did not fulfil the proportional hazards assumption and was therefore excluded from further analyses. All other variables included in the analysis fulfilled the required proportional hazards assumption. FPT modelling was performed in R (packages 'survival' and 'kinship').

The models were fitted separately for non-breeding and breeding areas. Movements between feeding and breeding areas were considered to be breeding movements and were hence analysed together with the breeding locations. Since non-breeding areas (summering areas) were generally located close to the coast and sea ice concentrations were not available in such areas, due to the land-masking process, sea ice concentration was not included as a covariate when modelling FPTs in these areas. Note that there was in fact little sea ice in coastal waters during the summers within the study period; the sea ice edge was located well north of the summering areas of the tracked walruses.

Summary statistics are hereafter presented as means $\pm \mathrm{SE}$ or as median values (with first and third quartile values). Since the number of locations varied between individuals (see Table 1), mean values obtained from data pooled across individuals are presented as the mean of the mean values of each individual. The same was done for the medians. 


\section{RESULTS}

\section{Movements, over-wintering and site fidelity}

Movement data for individual walruses were obtained for periods ranging from 2 to $18 \mathrm{mo}$ and included either part of, or the complete, breeding season for 16 of 17 individuals (Table 1). During summer, walruses were most often found in coastal areas; median distance to the coast was $4.6 \mathrm{~km}$ (3.7 to $5.6 \mathrm{~km})$. Monthly home ranges varied greatly between individuals (182 to $91113 \mathrm{~km}^{2}$ ). Large summer home ranges were mainly obtained from individuals moving along the coasts of Svalbard. Only 1 walrus performed an offshore trip (to FJL) during summer (walrus 2003_04; Fig. 1).

During winter, most walruses performed longdistance movements, reaching areas up to $840 \mathrm{~km}$ from the tagging locations (Figs. $1 \& 3$ ). They travelled up to $670 \mathrm{~km}$ (linear distance) in $10 \mathrm{~d}$. When they reached specific areas (assumed to be breeding areas), they occupied them for 20 to 226 d (Fig. 4); the mean period was $120 \pm 24 \mathrm{~d}$ for the individuals with known returning dates. Walruses performed offshore winter movements between early October and early February and returned between late February and late June (Fig. 4). During these trips, the walruses did not follow the ice edge as the sea ice advanced or retreated. Instead, they moved far into areas with increasing ice coverage, using areas as far as $600 \mathrm{~km}$ from ice-free areas, with

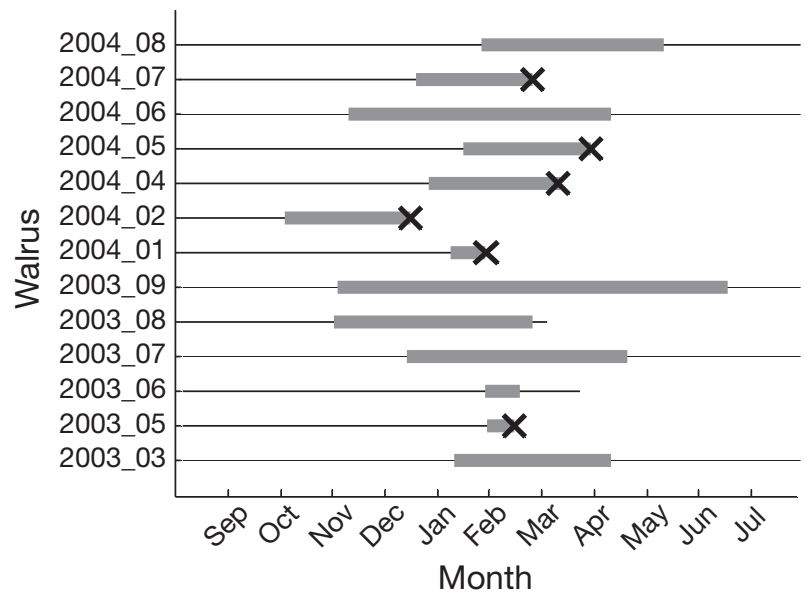

Fig. 4. Odobenus rosmarus. Time spent at the wintering/ breeding areas by male walruses tagged in Svalbard in 2003 and 2004 (thick lines). Thin lines indicate duration of the tracking records. Contact with some walruses was lost during the breeding season as indicated by the symbol $x$. Tick marks on the $x$-axis correspond to the first day of each month. Note that 4 walruses are not shown in the figure since they did not move to any particular breeding area during winter (2003_01, 2003_02 and 2003_04; see Figs. 1 \& 3) or there were no data available from winter (2004_03) ice concentrations as high as $100 \%$ (Fig. 5). Median sea ice coverage encountered along the paths of these trips was $84.5 \%$ (64.3 to $89.4 \%$; values calculated from locations at $6 \mathrm{~h}$ intervals along the tracks). The winter destinations of walruses were linked to their summer locations. Individuals tagged at 2 sites in the north of Svalbard, that were still sending data in winter $(n=7)$ performed relatively short winter trips, travelling only to the NE corner Svalbard $(n=4)$ or just to the east of Kvitøya (Figs. 1 \& 2, Table 1). Winter movements of walruses tagged in the southeast of Svalbard $(n=9)$ were more variable. Most of these males moved towards the northeast; 1 only went as far as the NE corner of Svalbard, 2 stopped just south and east of Kvitøya, while 2 others went as far as FJL (Figs. 1 \& 3, Table 1). Three individuals did not move toward the NE; 1 of these (walrus 2003_08) moved a significant distance coastally, going around the southern point of Spitsbergen to the west coast, while the other 2 (walruses 2003_01 and 2003_02) remained in their summer locations (Figs. 1 \& 3, Table 1). The 2 walruses that did not travel in winter, as well as walrus 2003_04, which did travel offshore, but during summer, were probably relatively young, based on their tusk volumes (Table 1).

After the breeding season, all of the walruses still sending locations $(n=5)$ showed fidelity to the previous year's summering areas, with home range overlaps were as high as $71 \%$ for the month of August (mean overlap was $35.0 \pm 12.7 \%$; see Fig. 6). Only 1 individual was tracked for a long enough period for positions to be obtained during a second winter (walrus 2004_08), and this tag only provided 2 locations during the second breeding season. But, both of these locations overlapped the MCP area used in the previous breeding season, located NE of Svalbard (see Fig. 1).

\section{Habitat selection}

The rankings of alternative $\mathrm{CPH}$ models for nonbreeding and breeding areas are shown in Tables 2 \& 3 , respectively. During the non-breeding season, FPTs at the radius of $40 \mathrm{~km}$ varied dramatically, ranging from $13 \mathrm{~h}$ to $189 \mathrm{~d}$ (mean: $31.7 \pm 6.2 \mathrm{~d}$ ). Areas of intense usage (high FPTs) occurred in shallow areas, close to the coast, as indicated by the bootstrapping confidence intervals (Fig. 7). The same pattern was obtained both when including or excluding the time spent hauled out. Accordingly, higher risk of leaving an area was found with increasing depths $(>40 \mathrm{~m})$ and at increased distance from the shore (Table 4). For example, the risk of leaving an area was 2.6 times higher in waters deeper than $80 \mathrm{~m}$ compared to areas shallower than $20 \mathrm{~m}$ (see hazard ratios in Table 4). In areas located at $>60 \mathrm{~km}$ from the coast, the risk of leaving was approxi- 


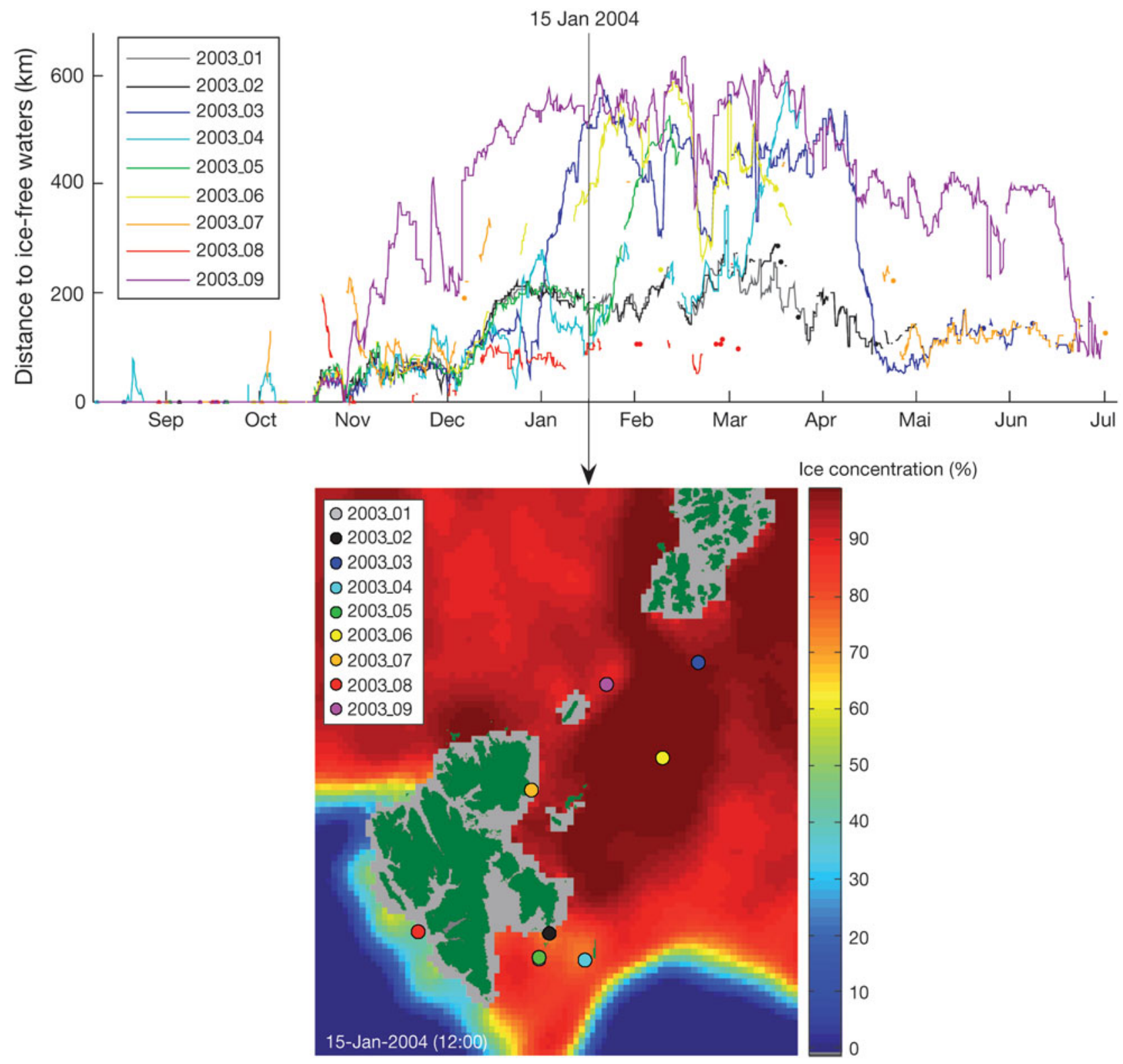

Fig. 5. Odobenus rosmarus. Distances to ice-free areas throughout the year for walruses tagged in Svalbard in August 2003 (upper panel). Tick marks on the $x$-axis correspond to the beginning (first day) of each month. Lower panel gives the location of the walruses on 15 January 2004, a day selected during the peak period of ice cover. Note that the locations of walruses 2003_01 and 2003_05 overlap. Sea ice concentrations in the lower panel range from 0 to $100 \%$. No ice information is available for the coastal areas shown in grey

mately 9 times higher than in areas up to $20 \mathrm{~km}$ from the coast. These 2 variables explained $57.1 \%$ of the variability in the data (Table 2 ). The variance component attributed to individual variability was 0.627 . The standard deviation of the per-individual random effects $(\sqrt{0.627} \approx 0.792)$ indicates that the average spread of relative risk of leaving among individuals was $\mathrm{e}^{0.792} \approx 2.21$, meaning that the per-individual variability in the probability of leaving was on average 2.2 times higher or smaller than the overall probability.
When using wintering/breeding areas, or when in transit to those areas, FPTs at the spatial scale of $40 \mathrm{~km}$ radius ranged from $20 \mathrm{~h}$ to $82 \mathrm{~d}$ (mean: $19.3 \pm 3.6 \mathrm{~d}$ ). Mean water depth used in these areas was $125 \pm$ $18.7 \mathrm{~m}$. Neither the bathymetry nor the proximity to a coastline affected FPTs during the winter season (see Tables 3 \& 5). Note that water depth was included in the most parsimonious model, but its effect on FPTs was not significant (see confidence intervals in Table 5). Higher risks of leaving were observed at the 
beginning and end of the breeding season (October and June), reflecting the transit to and from the breeding areas. Lower risks of leaving were also observed in ice-covered waters, but sea ice concentration and month together explained only $29.0 \%$ of the variability in the FPT data (Table 3). The variance component attributable to individual variability in the wintering/ breeding areas was 1.45 .
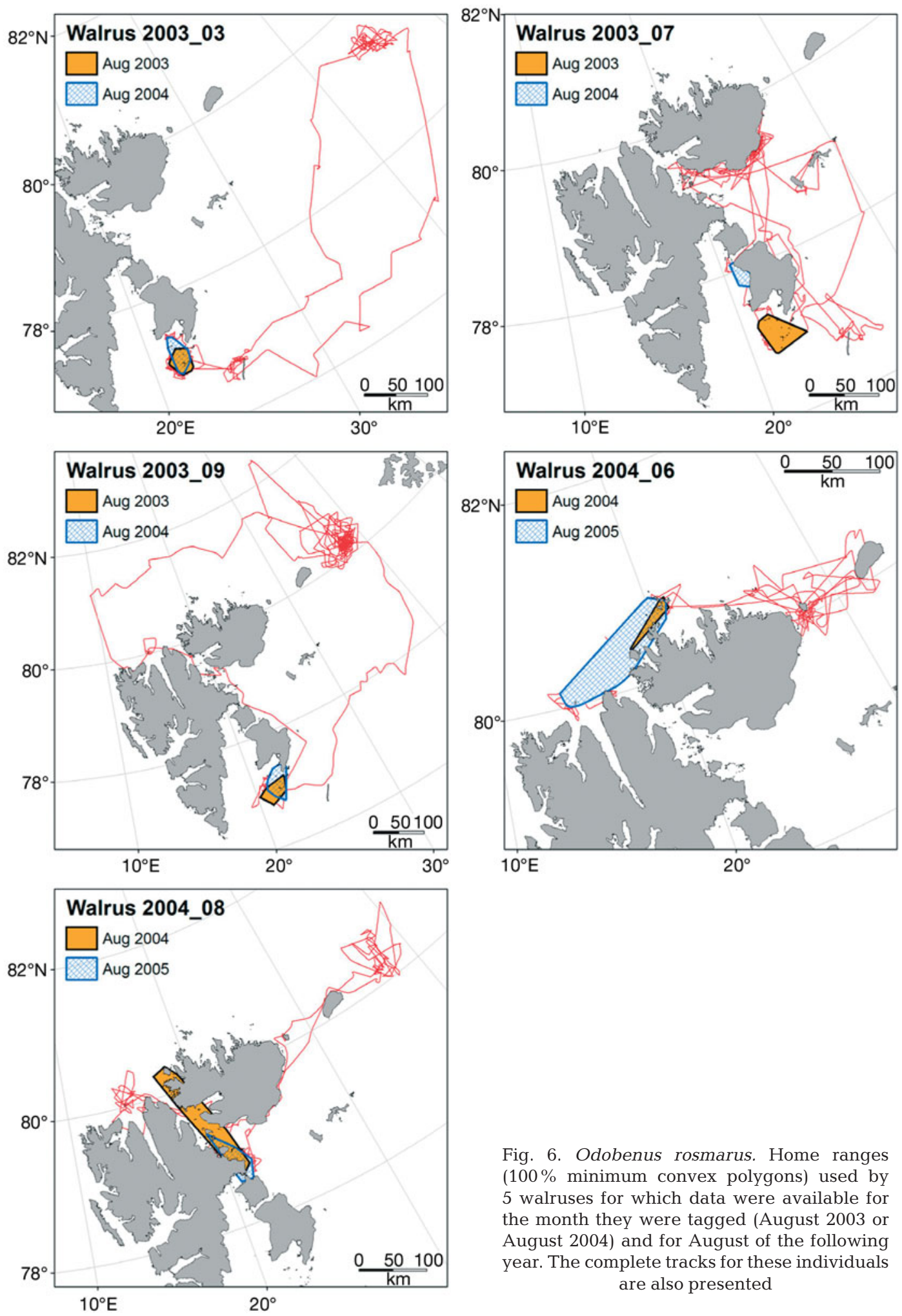

Fig. 6. Odobenus rosmarus. Home ranges (100\% minimum convex polygons) used by 5 walruses for which data were available for the month they were tagged (August 2003 or August 2004) and for August of the following year. The complete tracks for these individuals are also presented 
Table 2. Odobenus rosmarus. Model ranking (most parsimonious model at the top) for summer/non-breeding areas for walruses in Svalbard based on Akaike's information criteria corrected to the actual sample size $\left(\mathrm{AIC}_{\mathrm{c}}\right) . \mathrm{AIC}_{\mathrm{c}}$ differences $\left(\Delta_{i}\right)$, Akaike weights $\left(w_{i}\right)$ and coefficients of determination $\left(\mathrm{R}^{2}\right)$ are also presented, together with the penalised log-likelihoods $(\log (L))$ and penalised degrees of freedom (df) used to calculate the $\mathrm{AIC}_{\mathrm{c}}$ values. Sample size is 1564 . Depth: sea bottom depth (4 categories: $0-20 \mathrm{~m},>20-40 \mathrm{~m},>40-60 \mathrm{~m}$ and $>60 \mathrm{~m}$ ); Coast: distance to the coast (4 categories: $0-20 \mathrm{~km}$, $>20-40 \mathrm{~km},>40-60 \mathrm{~km}$ and $>60 \mathrm{~km}$ )

\begin{tabular}{|lcccccc|}
\hline Model & $\mathrm{AIC}_{\mathrm{c}}$ & $\Delta_{i}$ & $W_{i}$ & $\mathrm{R}^{2}$ & $\log (L)$ & $\mathrm{df}$ \\
\hline Depth + Coast & 18611.6 & 0 & 1.00 & 0.571 & -9283 & 22.6 \\
Depth & 18726.3 & 114.7 & 0.00 & 0.535 & -9344 & 18.6 \\
Coast & 18786.3 & 174.7 & 0.00 & 0.518 & -9373 & 19.6 \\
\hline
\end{tabular}

Table 3. Odobenus rosmarus. Model ranking (most parsimonious model at the top) for breeding areas for walruses tagged in Svalbard based on the Akaike's information criteria corrected to the actual sample size $\left(\mathrm{AIC}_{\mathrm{C}}\right) \cdot \mathrm{AIC}_{\mathrm{c}}$ differences $\left(\Delta_{i}\right)$, Akaike weights $\left(w_{i}\right)$ and coefficients of determination $\left(\mathrm{R}^{2}\right)$ are also presented, together with the penalised $\log$-likelihoods $(\log (L))$ and penalised degrees of freedom (df) used to calculate the $\mathrm{AIC}_{\mathrm{c}}$ values. Sample size is 634 . Conc: sea ice concentration (6 categories: $0 \%,>0-20 \%,>20-40 \%,>40-60 \%$, $>60-80 \%$ and $>80-100 \%$ ); Month: calendar month (9 categories: Jan, Feb, Mar, Apr, May, Jun, Oct, Nov and Dec); Depth: sea bottom depth (4 categories: 0-20 $\mathrm{m},>20-40 \mathrm{~m},>40-60 \mathrm{~m}$ and $>60 \mathrm{~m})$; Coast: distance to the coast ( 4 categories: $0-20 \mathrm{~km},>20-40 \mathrm{~km},>40-60 \mathrm{~km}$ and $>60 \mathrm{~km}$ )

\begin{tabular}{|lrrrrrr|}
\hline Model & $\mathrm{AIC}_{\mathrm{c}}$ & $\Delta_{i}$ & $W_{i}$ & $\mathrm{R}^{2}$ & $\log (L)$ & $\mathrm{df}$ \\
\hline Conc + Month + Depth & 4381.9 & 0 & 0.64 & 0.334 & -2164 & 26.14 \\
Conc + Month + Depth + Coast & 4383.0 & 1.1 & 0.36 & 0.339 & -2163 & 28.18 \\
Conc + Month & 4402.7 & 20.8 & 0.00 & 0.290 & -2179 & 22.26 \\
Conc + Month + Coast & 4405.8 & 23.9 & 0.00 & 0.291 & -2178 & 24.23 \\
Conc + Depth & 4434.7 & 52.8 & 0.00 & 0.218 & -2200 & 17.30 \\
Conc + Depth + Coast & 4434.9 & 53.0 & 0.00 & 0.226 & -2198 & 19.53 \\
Conc & 4458.2 & 76.3 & 0.00 & 0.162 & -2215 & 13.73 \\
Conc + Coast & 4460.8 & 78.9 & 0.00 & 0.165 & -2215 & 15.72 \\
Month + Depth + Coast & 6775.9 & 2394.0 & 0.00 & 0.267 & -3362 & 25.04 \\
Month & 6804.1 & 2422.2 & 0.00 & 0.218 & -3383 & 19.06 \\
Depth + Coast & 6823.5 & 2441.5 & 0.00 & 0.188 & -3395 & 16.64 \\
Depth & 6834.7 & 2452.8 & 0.00 & 0.166 & -3403 & 14.08 \\
Coast & 6847.0 & 2465.1 & 0.00 & 0.146 & -3411 & 12.84 \\
\hline
\end{tabular}

Table 4. Odobenus rosmarus. Estimated coefficients $(\beta)$, hazard ratios $\left(\mathrm{e}^{\beta}\right)$ and $95 \%$ confidence intervals $(\mathrm{CI}(\beta))$ of the mixed-effects Cox proportional hazards $(\mathrm{CPH})$ model for the covariates affecting the risk of leaving a non-breeding area by male walruses in Svalbard. Numbers of locations in each category are also given (n). Note: A $\beta$-value $>0\left(\mathrm{e}^{\beta}>1\right)$ indicates an increased risk of leaving, while a $\beta$-value $<0\left(e^{\beta}<1\right)$ is interpreted in the opposite way

\begin{tabular}{|lrccc|}
\hline Variable & $\mathrm{n}$ & $\beta$ & $\mathrm{e}^{\beta}$ & $\mathrm{CI}(\beta)$ \\
\hline Depth $(\leq 20 \mathrm{~m})$ & 478 & - & - & - \\
Depth $(>20-40 \mathrm{~m})$ & 429 & -0.019 & 0.981 & -0.16 to 0.12 \\
Depth $(>40-60 \mathrm{~m})$ & 205 & 0.352 & 1.422 & 0.18 to 0.53 \\
Depth $(>60-80 \mathrm{~m})$ & 93 & 0.503 & 1.653 & 0.26 to 0.75 \\
Depth $(>80 \mathrm{~m})$ & 359 & 0.969 & 2.635 & 0.79 to 1.15 \\
Distance to coast $(\leq 20 \mathrm{~km})$ & 1321 & - & - & - \\
Distance to coast $(>20-40 \mathrm{~km})$ & 111 & 0.659 & 1.932 & 0.44 to 0.88 \\
Distance to coast $(>40-60 \mathrm{~km})$ & 45 & 1.223 & 3.396 & 0.87 to 1.57 \\
Distance to coast $(>60 \mathrm{~km})$ & 87 & 2.192 & 8.951 & 1.88 to 2.50 \\
\hline
\end{tabular}

\section{DISCUSSION}

A number of new aspects of walrus natural history were revealed by this study and some previous suggestions, based on observations of one or a very few individuals, regarding wintering behaviours were confirmed. During the summer season walruses in Svalbard used coastal, shallow waters, similar to other areas within the species' range. During this non-breeding season, walruses would be expected to seek out places with abundant food resources near areas with appropriate haulout platforms for resting. The coastal areas of Svalbard clearly provide both. The diving behaviour of the studied walruses demonstrated that most of the dives performed during summer reached the sea floor, suggesting intensive feeding activity during this period. Note that, although these walruses spend approximately $25 \%$ of the time hauled out during summer (Lydersen et al. 2008), the long FPTs observed in this study close to the coast and in shallow waters were independent of whether the time spent hauled out was included in the analysis or not.

The fact that walrus populations exhibit strong site fidelity with regard to summering haulout sites, over extended periods of time, has been known for thousands of years; this behaviour has been actively exploited by northern people who have hunted walrus for generations (Fay 1982). However, the present study has confirmed suggestions made previously that it is not just a population level phenomenon. All of the walruses in this study that were tracked for periods in excess of a year showed fidelity to previously used feeding areas in consecutive years. Homing behaviour, i.e. the use of a previously occupied home range, has been reported previously for Pacific walruses (Jay \& Hills 2005) and for 1 male Atlantic walrus in Greenland (Born et al. 

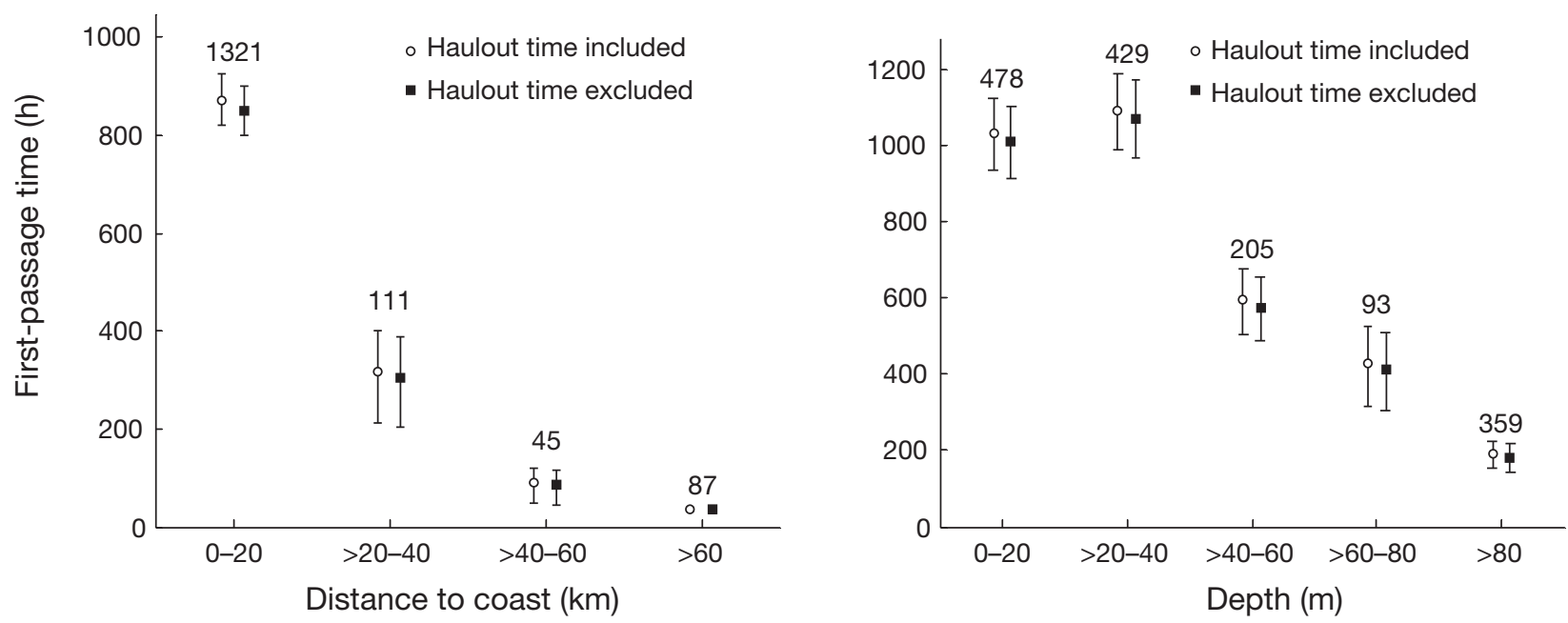

Fig. 7. Odobenus rosmarus. Bootstrapping means and $95 \%$ confidence intervals (CI) of the first-passage time (40 km radius) at distinct distances to the coast (left panel) and depth (right panel) for male walruses in Svalbard, during the summer/non-breeding season. Means and CIs are given, both including and excluding the time walruses spent hauled out on land or ice. Numbers of locations within each category are displayed above each CI line

2005). This behaviour is perhaps not surprising given that the food resources (bivalves and other benthic invertebrates) of walruses are relatively predictable in a spatial sense compared to pelagic food resources, which are highly dynamic in space and time (Sims et al. 2008). Knowledge gained via experience in finding food resources in particular areas is likely at least a partial cause for the observed fidelity by individual walruses. Some of the walruses in this study moved significant distances from the wintering/breeding areas back to the summering/feeding areas. The navigation mechanisms used by walruses are unknown, but walruses have been reported to follow the same migration route in different years, independent of sea ice concentrations (Born et al. 2005). The only walrus tracked in this study during 2 consecutive wintering seasons showed fidelity to the previous year's breeding area. Similar fidelity to a wintering/breeding area was also reported for 1 walrus in Greenland (Born et al. 2005).

This study identified areas that are probably used as breeding locations, based on movement and diving patterns of the male walruses. Most of these areas were located between the northeast corner of Svalbard and FJL. Although walruses from Svalbard and
FJL are known to belong to the same population (Born et al. 1995, Andersen et al. 1998), and movements of male walruses from Svalbard to FJL have been previously observed outside the breeding season (Wiig et al. 1996), this is the first time that movements to FJL during the breeding season have been conclusively

Table 5. Odobenus rosmarus. Estimated coefficients $(\beta)$, hazard ratios $\left(\mathrm{e}^{\beta}\right)$ and $95 \%$ confidence intervals $(\mathrm{CI}(\beta))$ for wintering/breeding areas for walruses from Svalbard for the mixed-effects Cox proportional hazards model selected according to the $\mathrm{AIC}_{\mathrm{c}}$. Numbers of locations in each category are also given (n). Note: $A \beta$-value $>0\left(e^{\beta}>1\right)$ indicates an increased risk of leaving, while a $\beta$-value $<0\left(\mathrm{e}^{\beta}<1\right)$ is interpreted in the opposite way

\begin{tabular}{|lrrcc|}
\hline Variable & $\mathrm{n}$ & $\beta$ & $\mathrm{e}^{\beta}$ & $\mathrm{CI}(\beta)$ \\
\hline Depth $(\leq 20 \mathrm{~m})$ & 50 & - & - & - \\
Depth $(>20-40 \mathrm{~m})$ & 33 & -0.354 & 0.702 & -1.37 to 0.66 \\
Depth $(>40-60 \mathrm{~m})$ & 55 & -0.683 & 0.505 & -1.55 to 0.18 \\
Depth $(>60-80 \mathrm{~m})$ & 71 & -0.309 & 0.734 & -1.15 to 0.54 \\
Depth (>80 m) & 425 & 0.246 & 1.279 & -0.55 to 1.04 \\
Month (Jan) & 157 & - & - & - \\
Month (Feb) & 121 & -0.218 & 0.804 & -0.51 to 0.08 \\
Month (Mar) & 68 & -0.023 & 0.977 & -0.37 to 0.33 \\
Month (Apr) & 62 & -0.313 & 0.731 & -0.71 to 0.09 \\
Month (May) & 35 & 0.091 & 1.095 & -0.46 to 0.64 \\
Month (Jun) & 26 & 1.048 & 2.852 & 0.53 to 1.57 \\
Month (Oct) & 32 & 1.728 & 5.630 & 0.81 to 2.64 \\
Month (Nov) & 52 & -1.056 & 0.348 & -1.61 to -0.51 \\
Month (Dec) & 81 & -0.369 & 0.691 & -0.76 to 0.02 \\
Ice concentration $(0-20 \%)$ & 24 & - & - & - \\
Ice concentration $(>20-40 \%)$ & 21 & -1.226 & 0.293 & -2.12 to -0.34 \\
Ice concentration $(>40-60 \%)$ & 24 & -0.573 & 0.564 & -1.46 to 0.31 \\
Ice concentration $(>60-80 \%)$ & 72 & -0.916 & 0.400 & -1.81 to -0.03 \\
Ice concentration $(>80-100 \%)$ & 301 & -1.234 & 0.291 & -2.13 to -0.34 \\
\hline
\end{tabular}



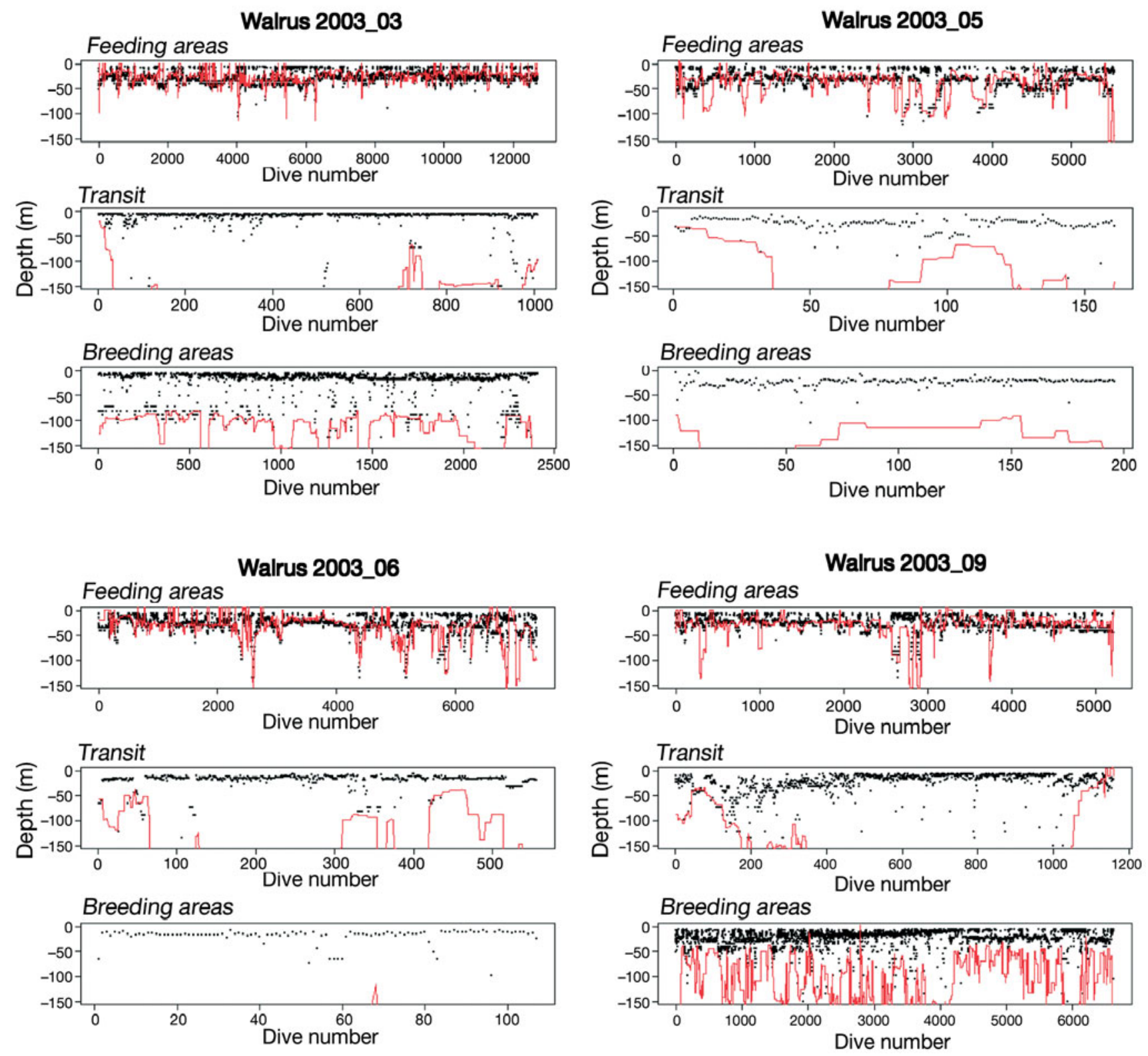

Fig. 8. Odobenus rosmarus. Maximum depth of the dives recorded for 4 of the tracked walruses in summering areas, wintering areas and when in transit between such areas. Sea bottom depth $(\leq 150 \mathrm{~m})$ is also shown (red line). Dives that extend below the sea floor are due to either animal location errors, or more likely, lack of precision in the bathymetric data

documented. Interestingly, walruses feeding in the south of Svalbard during summer usually travelled to FJL or to the pack ice between the 2 archipelagos, while walruses summering in the north of Svalbard did not go all the way to FJL, even though the distance is shorter for these individuals. This is probably because females can be found closer at hand. Female walruses have been observed in the northeast corner of Svalbard during summer (Gjertz \& Wiig 1994; C. Freitas, K. M. Kovacs, M. A. Fedak and C. Lydersen pers. obs.), so it is very likely that male walruses summering in the north of the archipelago are aware of their presence. A previous study by Wiig et al. (1996) reported trips by male walruses from Svalbard to FJL outside the breeding season, and these were interpreted as reconnaissance trips for females. One individual in this study performed 1 such out-of-season trip. However, this male did not return to the areas visited in the autumn during the breeding period, at least prior to March when this individual's transmitter ceased functioning.

The male movement patterns observed in the present study support the conjecture that breeding in this population occurs mainly between January and March, and perhaps extends later into the spring; this 
latter point could not be tested with rigor because several of the SRDLs ceased to transmit during the spring. Atlantic walruses in Greenland and Canada also breed mainly between January and April (Mansfield 1966, Sjare \& Stirling 1996, Born 2001, 2003), although sexually active males can be found from November to July (Mansfield 1958, Born 2003) and females in oestrus can be found from January to June (Born 2001). The mating system in walruses has been described as a lek or a female-defence polygyny system (Fay et al. 1984, Sjare \& Stirling 1996), where females and calves haulout on the ice or rest in the water, while males station themselves alongside female groups and perform complex, stereotyped underwater songs (Fay 1982, Fay et al. 1984, Sjare \& Stirling 1996). In the Atlantic it seems that a single male has exclusive access to a small herd during a given period of time ( 1 to $5 \mathrm{~d}$ ), after which it is replaced by another male, with some males attending the female herds significantly more often that others (Sjare \& Stirling 1996). The invasion of a male's display area can result in agonistic displays and sometimes intensive fights (Fay 1982, Fay et al. 1984, Sjare \& Stirling 1996). It is possible that males move to breeding areas before females become reproductively active, to establish themselves in areas where the different groups of females are located, to interact with potential competitors and perhaps also to establish dominance relationships so that they can attempt female attendance as early as is possible.

Walruses in the Pacific are thought to follow the seasonal advances and retreats of sea ice throughout the year (Fay 1982), and the same pattern has been assumed to be followed by Atlantic walruses, because these animals can only break though ice up to about $20 \mathrm{~cm}$ thick (Born et al. 1995). However, 1 individual tracked by Born et al. (2005) in Greenland during winter used waters with extensive ice coverage (>90\%). Similarly, this study also provides evidence that walruses use areas with very extensive ice cover (>90\%), as far as $600 \mathrm{~km}$ from ice-free areas. It should be noted that drifting ice, identified by remote sensing as > $90 \%$ ice concentration, still provides significant amounts of open water and does not necessarily imply the need to break through thick sea ice to breathe at the surface. Other species, such as white whales Delphinapterus leucas, which cannot break though thick ice, have been reported to move distances of $700 \mathrm{~km}$ through areas of $>90 \%$ ice cover (Suydam et al. 2001).

The intensities of habitat use by walrus both during transit to, and when in, breeding areas were independent of water depth and distance to the coast. Because offshore areas were frequently ice covered, access to resting platforms was not a constraint. The areas where males concentrated their time during the winter breeding season were considerably deeper than within their summer feeding areas. Fay (1982) suggested that male Pacific walruses fed very little during the breeding season. The diving behaviour analysed in this study from the time when walruses were in the winter offshore areas reveals that male walruses do not often dive to the sea bottom at this time. This suggests that feeding activity was probably very limited while they were in breeding areas. However, female Pacific walruses do feed during the winter/breeding period according to Fay (1982), especially if they are pregnant or lactating. It is therefore somewhat surprising that the males in this study were in such deep areas during the breeding season, when they were presumably attending females. There are no data on female locations during winter for this population, but the observed male movements at the time when breeding is known to occur for walruses suggest the presence of females in those areas. It might be that the presence of closely packed drift ice in those areas provides a more stable environment for females and their calves, compared with more open ice areas, such as those found in the marginal ice zones. It might also be that diving and foraging at depths $>100 \mathrm{~m}$ is not a constraint for female walruses. Little is currently known about the water masses seasonally in these areas, so it is not possible to determine what environmental attributes beyond the ice quality might be involved in determining wintering areas.

In summary, the over-wintering movements of the study walruses revealed that during the Arctic winter, male Atlantic walruses actively travel though areas of dense ice cover; they do not follow the sea ice advances and retreats. The main breeding areas for the Svalbard/FJL population are located in ice-covered waters between northeast Svalbard and FJL, as was hypothesised by Wiig et al. (1996). Breeding seems to occur mainly from January to March (and maybe into April). Walrus habitat use changes markedly between seasons. In summer, habitat use appears to be driven by the feeding needs in combination with available haulout areas, which includes land and also summer pack-ice whenever it is available in coastal areas, though this is not common (K. M. Kovacs \& C. Lydersen pers. obs.); summer habitat use is strongly affected by water depth and distance to the coast. Winter habitat use seems to be driven by breeding needs and was, in this study, independent of water depth and distance to shore. Males seem to feed little during the breeding season and their habitat selection is probably mainly affected by the presence of females. Seasonal site fidelity seems to be strong from year to year in both summer and winter for individual walruses. This study has advanced our knowledge regarding movement patterns and habitat selection, particularly in winter, for male walruses, but many questions remain unan- 
swered. Potential geographic differences in movement patterns need to be explored and a much broader geographical area needs to be studied with the new satellite technology. Tagging female walruses in the near future will be essential in order to develop a more complete understanding of the winter ecology of this species. The females' location choices presumably determine the winter distribution of males; and females face more complex habitat choices because of their need to feed throughout the year, including times when they are pregnant or nurturing young. One ongoing problem for habitat assessment work in remote regions is that environmental data are often quite limited in such areas, where even fundamental marine data such as bathymetry are missing for large geographic sectors. However, these data are likely to improve rapidly in the near future. The safe-handling procedures developed during this study programme for walruses, as well as the more broadly applicable advances in tracking technologies and spatial analyses, make it more feasible/justifiable to work with male and female walruses in the future. Some of these latter developments are also relevant for other large marine mammals in remote, changing regions, where satellite-tracking technologies are certain to permit more complete assessments of the ecology of these species in the decades to come.

Acknowledgements. The authors thank P. Lovell, C. Hunter and the other members of the instrumentation group at SMRU for their efforts during the development phases of the walrusmodified SRDLs. We also thank D. Griffiths and H. Eggenfellner for their help with the deployments during 2003 and 2004. Sea ice data were provided by OSI-SAF, and data-access support was kindly given by S. Eastwood. This study was financially supported by the Norwegian Research Council (NRC/ NFR) and the Norwegian Polar Institute. C.F. was funded by a studentship provided by the Fundação para a Ciência e a Tecnologia (FCT), Portugal.

\section{LITERATURE CITED}

Aarts G, Mackenzie M, McConnell B, Fedak M, Mathiopoulos $\mathrm{J}$ (2008) Estimating space-use and habitat preference from wildlife telemetry data. Ecography 31:140-160

ACIA (Arctic Climate Impact Assessment) (2005) Impacts of a warming Arctic. Cambridge University Press, Cambridge

Allen JA (1880) North American pinnipeds. A monograph of the walruses, sea-lions, sea-bears and seals of North America. US Geological and Geographical Survey of the Territories, Misc Publ 12. GPO, Washington, DC

Andersen LW, Born EW, Gjertz I, Wiig Ø, Holm LE, Bendixen C (1998) Population structure and gene flow of the Atlantic walrus (Odobenus rosmarus rosmarus) in the eastern Atlantic Arctic based on mitochondrial DNA and microsatellite variation. Mol Ecol 7:1323-1336

Argos (1996) User's manual. CLS/Service Argos, Toulouse

$>$ Born EW (1984) Status of the Atlantic walrus Odobenus rosmarus rosmarus in the Svalbard area. Polar Res 2:27-45

Born EW (2001) Reproduction in female Atlantic walruses
(Odobenus rosmarus rosmarus) from north-west Greenland. J Zool (Lond) 255:165-174

Born EW (2003) Reproduction in male Atlantic walruses (Odobenus rosmarus rosmarus) from the North Water (N Baffin Bay). Mar Mamm Sci 19:819-831

Born EW, Acquarone M (2007) Estimation of walrus (Odobenus rosmarus) predation on bivalves in the Young Sound area (NE Greenland). Medd Grønland Biosci 58:176-191

Born EW, Knutsen LO (1992) Satellite-linked radio tracking of Atlantic walruses (Odobenus rosmarus rosmarus) in northeastern Greenland, 1989-1991. Z Saugetierkd 57: 275-287

Born EW, Knutsen LO (1997) Haul-out and diving activity of male Atlantic walruses (Odobenus rosmarus rosmarus) in NE Greenland. J Zool (Lond) 243:381-396

Born EW, Gjertz I, Reeves RR (1995) Population assessment of Atlantic walrus. Norsk Polarinst Medd 138:1-100

Born EW, Rysgaard S, Ehlme G, Sejr M, Acquarone M, Levermann N (2003) Underwater observations of foraging freeliving Atlantic walruses (Odobenus rosmarus rosmarus) and estimates of their food consumption. Polar Biol 26: 348-357

Born EW, Acquarone M, Knutsen LØ, Toudal L (2005) Homing behaviour in an Atlantic walrus (Odobenus rosmarus rosmarus). Aquat Mamm 31:23-33

Burnham KP, Anderson DR (2002) Model selection and multimodel inference: a practical information-theoretic approach. Springer-Verlag, New York, NY

Collett D (2003) Modelling survival data in medical research. Chapman \& Hall/CRC, Boca Raton, FL

Cooke SJ, Hinch SG, Wikelski M, Andrews RD, Kuchel LJ, Wolcott TG, Butler PJ (2004) Biotelemetry: a mechanistic approach to ecology. Trends Ecol Evol 19:334-343

Cox DR (1972) Regression models and life tables (with discussion). J Roy Stat Soc B 74:187-220

Fauchald P, Tveraa T (2003) Using first-passage time in the analysis of area-restricted search and habitat selection. Ecology 84:282-288

Fauchald P, Tveraa T (2006) Hierarchical patch dynamics and animal movement pattern. Oecologia 149:383-395

Fay FH (1982) Ecology and biology of the Pacific walrus, Odobenus rosmarus divergens Illiger. North American Fauna. US Department of the Interior, Fish and Wildlife Service 74:1-279

Fay FH (1985) Odobenus rosmarus. Mamm Species 238(Spec): $1-7$

Fay FH, Ray GC, Kibal'chich AA (1984) Time and location of mating and associated behavior of the Pacific walrus, Odobenus rosmarus divergens Illiger. NOAA Tech Rep 12:89-99

Fedak M, Lovell P, McConnell B, Hunter C (2002) Overcoming the constraints of long range radio telemetry from animals: getting more useful data from smaller packages. Integr Comp Biol 42:3-10

Fisher KI, Stewart REA (1997) Summer foods of Atlantic walrus, Odobenus rosmarus rosmarus, in northern Foxe Basin, Northwest Territories. Can J Zool 75:1166-1175

Fortin MJ, Dale M (2005) Spatial analysis. Cambridge University Press, Cambridge

Freitas C, Kovacs KM, Ims RA, Fedak MA, Lydersen C (2008a) Ringed seal post-moulting movement tactics and habitat selection. Oecologia 155:193-204

Freitas C, Kovacs KM, Lydersen C, Ims RA (2008b) A novel method for quantifying habitat selection and predicting habitat use. J Appl Ecol 45:1213-1220

Freitas C, Lydersen C, Fedak MA, Kovacs KM (2008c) A simple new algorithm to filter marine mammal Argos locations. Mar Mamm Sci 24:315-325 
Gjertz I, Wiig Ø (1992) Feeding of walrus Odobenus rosmarus in Svalbard. Polar Rec (Gr Brit) 28:57-59

Gjertz I, Wiig Ø (1994) Past and present distribution of walruses in Svalbard. Arctic 47:34-42

Gjertz I, Wiig Ø (1995) The number of walruses (Odobenus rosmarus) in Svalbard in summer. Polar Biol 15:527-530

Gjertz I, Griffiths D, Krafft BA, Lydersen C, Wiig Ø (2001) Diving and haul-out patterns of walruses Odobenus rosmarus on Svalbard. Polar Biol 24:314-319

Griffiths D, Wiig O, Gjertz I (1993) Immobilization of walrus with etorphine hydrochloride and zoletil ${ }^{\circledR}$. Mar Mamm Sci 9:250-257

Jay CV, Hills S (2005) Movements of walruses radio-tagged in Bristol Bay, Alaska. Arctic 58:192-202

Knutsen LØ (1993) Walrus studies in the Franz Josef Land Archipelago during August 1992. Norsk Polarinst Medd 126:1-16

Lønø O (1972) The catch of walrus Odobaenus rosmarus in the areas of Svalbard, Novaya Zemlya and Franz Josef Land. Norsk Polarinst Årbok 1970:199-212

Lydersen C, Martin AR, Kovacs KM, Gjertz I (2001) Summer and autumn movements of white whales Delphinapterus leucas in Svalbard, Norway. Mar Ecol Prog Ser 219:265-274

Lydersen C, Aars J, Kovacs KM (2008) Estimating the number of walruses in Svalbard based on aerial surveys and behavioural data from satellite telemetry. Arctic 61: $119-128$

Manly BFJ, McDonald LL, Thomas DL, McDonald TL, Erikson WP (2002) Resource selection by animals: statistical design and analysis for field studies. Kluwer Academic Publishers, Dordrecht

Manning TH (1944) Hunting implements and methods of the present-day Eskimos of north-west Hudson Bay, Melville Peninsula and south-west Baffin Island. Geogr J 103: $137-152$

Mansfield AW (1958) The biology of the Atlantic walrus Odobenus rosmarus rosmarus. Fish Res Board Can Man Rep Ser 653:1-146

Mansfield AW (1966) The walrus in Canada's Arctic. Can Geogr J 72:88-95

McConnell B, Bryant E, Hunter C, Lovell P, Hall A (2004)

Editorial responsibility: Hans Heinrich Janssen, Oldendorf/Luhe, Germany
Phoning home - a new GSM mobile phone telemetry system to collect mark-recapture data. Mar Mamm Sci 20: $274-283$

Miller EH (1982) Herd organization and female threat behavior in Atlantic walruses Odobenus rosmarus rosmarus (L). Mammalia 46:29-34

Miller EH, Boness DJ (1983) Summer behavior of Atlantic walruses Odobenus rosmarus rosmarus (L) at Coats Island, NWT (Canada). Z Saugetierkd 48:298-313

Mohr CO (1947) Table of equivalent populations of North American small mammals. Am Midl Nat 37:223-249

Pankratz VS, de Andrade M, Therneau TM (2005) Randomeffects Cox proportional hazards model: general variance component methods for time-to-event data. Genet Epidemiol 28:97-109

Robinson PW, Costa DP, Arnould J, Weise M and others (2006) Animal tracking ARGOS vs GPS. Eos Trans AGU 87:Fall Meet Suppl, Abstract OS33C-1716

Sims DW, Southall EJ, Humphries NE, Hays GC and others (2008) Scaling laws of marine predator search behaviour. Nature 451:1098-1102

Sjare B, Stirling I (1996) The breeding behavior of Atlantic walruses, Odobenus rosmarus rosmarus, in the Canadian High Arctic. Can J Zool 74:897-911

Solomon S, Qin D, Manning M, Chen Z and others (2007) Climate change 2007: the physical science basis. In: Contributions of Working Group I to the 4th assessment report of the Intergovernmental Panel on Climate Change. Cambridge University Press, Cambridge

- Stewart REA, Outridge PM, Stern RA (2003) Walrus lifehistory movements reconstructed from lead isotopes in annual layers of teeth. Mar Mamm Sci 19:806-818

Suydam RS, Lowry LF, Frost KJ, O'Corry-Crowe GM, Pikok D (2001) Satellite tracking of eastern Chukchi Sea beluga whales into the Arctic Ocean. Arctic 54:237-243

Wiig Ø, Gjertz I, Griffiths D, Lydersen C (1993) Diving patterns of an Atlantic walrus Odobenus rosmarus rosmarus near Svalbard. Polar Biol 13:71-72

Wiig Ø, Gjertz I, Griffiths D (1996) Migration of walruses (Odobenus rosmarus) in the Svalbard and Franz Josef Land area. J Zool (Lond) 238:769-784

Submitted: February 1, 2008; Accepted: September 3, 2008 Proofs received from author(s): January 5, 2009 